\title{
Effects of Certain Penicillins on Growth and Cell Division in a Species of Erwinia
}

\author{
By MARY M. GRULA and E. A. GRULA \\ Department of Microbiology, Oklahoma State University, \\ Stillwater, Oklahoma, U.S.A.
}

(Received 30 October 1964)

\begin{abstract}
SUMMARY
By using growth and division-inhibition at $16 \mathrm{hr}$ as indices of activity, eight penicillins, differing in the side chain, were tested against an Errvinia species, and compared with benzylpenicillin. DL- $\alpha$-Aminobenzylpenicillin, DL-3-chloro- $\alpha$-aminobenzylpenicillin, $\mathrm{D}$ - $\alpha$-aminobenzylpenicillin, and methicillin were more toxic for growth than was benzylpenicillin. 6Aminopenicillanic acid and cloxacillin were about equal to benzylpenicillin in toxicity; triphenylmethylpenicillin and 2-ethoxy-1-naphthylpenicillin were much less toxic. All the compounds inhibited division of the bacteria but, at $50 \%$ of normal growth, methicillin, cloxacillin and 2-ethoxy-1naphthylpenicillin resulted in significantly longer organisms than the others. Pantoyl lactone, when present in the medium from the time of inoculation, in all cases decreased the length of the organisms, increased growth (with a highly toxic concentration of penicillin), and decreased the accumulation of keto acids and ultraviolet-absorbing materials in the medium. It was concluded that the side chain of these penicillins is not essential for the inhibition of growth and division of this Ervinia sp.; quantitative differences in activity associated with the side chain appear to result from the influence of the side chain on factors such as penetration, or strength of binding at the active site.
\end{abstract}

\section{INTRODUCTION}

The relationship of the structure of the side chain to the activity of various penicillin derivatives against Gram-negative bacteria has not been extensively studied. According to Cooper (1956) the side chain of benzylpenicillin is not important for activity against Gram-positive organisms. However, Russell (1962) observed that 6-(2,6-dimethoxybenzamido)penicillinic acid (dimethoxyphenylpenicillin, Celbenin, methicillin) was by far the least toxic of a series of penicillins for Escherichia coli. Boman \& Eriksson (1963), using the minimum concentration necessary to produce lysis of $E$. coli $\mathrm{K}-12$ in one generation during log. phase as an index of activity, reported that the side-chain structure markedly influenced activity. They found, in agreement with other workers (Rolinson \& Stevens, 1961; Rogers \& Mandelstam, 1962), that D- $\alpha$-aminobenzylpenicillin (D-ampicillin) was considerably more active than benzylpenicillin (penicillin G). The concentration which produced lysis in one generation ('LIOG' value) was about one-tenth as great for $\mathrm{D}$-ampicillin as for benzylpenicillin. D-Ampicillin was about three times as active as L-ampicillin. Boman \& Eriksson (1963) found that, in general, aminoalkyl and aminobenzylpenicillins were very active. One exception noted by Cooper (1956) 
to the generalization that the side chain was not important for activity toward Gram-positive bacteria was the activity of cephalosporin $\mathbf{N}$, a penicillin which contains $\alpha$-aminoadipic acid as the side chain (Abraham et al. 1953). Boman \& Eriksson (1963) also reported that bulky 'non-biological' side chains greatly decreased the antibiotic activity; two such derivatives, methicillin and 3-p-chlorophenyl-4(1,2,5-oxodiazole)-penicillin, were less active than 6-aminopenicillanic acid. The latter compound, lacking a side chain, was one-tenth as potent as benzylpenicillin. By using a different approach, i.e. the ability of a penicillin to inhibit growth and bacterial division when present in the medium from the time of inoculation, we have compared eight penicillins which differ in the side chain, in their activity against an Erwinia.

\section{METHODS}

The strain of Erwinia sp. used and its maintenance were described previously (Grula, $1960 a$ ). Tests of antibacterial activity of the penicillins were made in the defined medium of Grula $(1960 \mathrm{~b})$; glucose (autoclaved separately), penicillin, and pantoyl lactone (each filter sterilized) were added just before inoculation. Stock aqueous solutions of the penicillins were always prepared just before use; the correct volume was placed in the medium (buffered at $\mathrm{pH} \mathrm{7}$ ) less than $20 \mathrm{~min}$. after preparation. Sjöberg \& Ekström (see Boman \& Eriksson, 1963) found that the halflife of D-ampicillin at $\mathrm{pH} 7$ and $37^{\circ}$ was about $100 \mathrm{hr}$; that of L-ampicillin $15 \mathrm{hr}$. Since we found DL-ampicillin just as toxic as D-ampicillin, it can be concluded that decomposition of L-ampicillin was not a factor in its observed toxicity.

DL-Pantoyl lactone was bought from Mann Research Laboratories (136 Liberty Street, New York). Stock solutions, adjusted to $\mathrm{pH} 6 \cdot 8$, could be stored for at least 6 weeks at $4^{\circ}$ with no decrease in analytical concentration of lactone.

Five-ml. lots of medium were inoculated with $0.05 \mathrm{ml}$. of a twice-washed standardized suspension of bacteria from a 24-hr nutrient agar slope. After $16 \mathrm{hr}$ at $25^{\circ}$, with shaking, the cultures were examined for growth and length of organisms. The relative amount of growth was determined by measuring the extinction at $540 \mathrm{~m} \mu\left(E_{540}\right)$ with a Bausch and Lomb Spectronic 20 spectrophotometer. The lengths of organisms were determined as given by Grula \& Grula (1962). The average bacterial length given in Table 1 is an arithmetic mean, determined from a size distribution curve, of about 500 bacteria. Bacteria grown without antibiotic under these conditions were uniformly 2-5 $\mu$ long at $16 \mathrm{hr}$. Cultures of very high average bacterial length showed a lesser variability in length; for example, $70 \%$ of the culture might consist of filaments $>100 \mu$ long.

After removal of samples for growth and length determinations, cultures were centrifuged and the supernatant fluids analysed for total keto acid by the method of Haidle \& Knight (1960). Extinctions at 260 and $280 \mathrm{~m} \mu$ were measured with a Beckman DU spectrophotometer, with corrections made for the absorption by the penicillin when necessary.

The strain of Erwinia used has never shown evidence of having either a $\beta$-lactamase or an amidase for benzylpenicillin. Tests showed that the effects of benzylpenicillin were independent of inoculum size over a $2 \cdot 5$-fold range. 


\section{RESULTS}

Effects of various penicillins on growth and bacterial division

All the penicillin derivatives tested had some toxicity for the Erwinia strain used (Table 1). In accordance with the results of others (Rolinson \& Stevens, 1961; Rogers \& Mandelstam, 1962; Boman \& Eriksson, 1963) we observed that the aminobenzylpenicillins were more toxic than benzylpenicillin. The difference between $D L-\alpha$-aminobenzylpenicillin $(D: L=6: 4)$ and the pure $D$-isomer were not such as to indicate a 3 -fold higher activity of the pure D-compound, as reported by Boman \& Eriksson (1963).

The only other compound as toxic as the aminobenzylpenicillins was methicillin. This result was in contrast to the results of Boman \& Eriksson (1963), who found that methicillin possessed almost no lytic activity for Escherichia coli, and to the results of Russell (1962), who used inhibition of growth in nutrient broth and spheroplast formation as indices of activity. Two compounds (triphenylmethylpenicillin, 2-ethoxy-1-naphthylpenicillin), neither of which was tested by Boman \& Eriksson, inhibited growth only at concentrations at least three times greater than inhibitory concentrations of benzylpenicillin.

All the derivatives tested inhibited bacterial division (Table 1), resulting in the formation of filaments. Some compounds induced the formation of very long filaments at a concentration which allowed relatively good growth. With other compounds, the average bacterial length was not very great even at concentrations rather inhibitory of growth. The basis of this partial independence of the growthinhibitory and division-inhibitory properties of these penicillins is not known: it might indicate possible multiple sites of action.

All the penicillins used caused accumulation of relatively large amounts of keto acids and of ultraviolet-absorbing materials in the culture fluids (Table 2). The latter effect in particular is indicative of leakage, probably resulting from damage to the cell membrane.

\section{Annulment by pantoyl lactone of the growth-and division-inhibitory effects of penicillins}

Pantoyl lactone prevents filament formation by benzylpenfillin when in the medium from the time of inoculation, and also annuls growth-inhibitory effects when present at the proper concentration relative to the penicillin concentration (Grula \& Grula, 1962); higher concentrations are toxic. Pantoyl lactone prevents benzylpenicillin-induced release of ultraviolet-absorbing materials into the growth medium, and greatly decreases the accumulation of keto acids (Grula \& Grula, 1964). In the absence of any inhibitory agent pantoyl lactone has little effect on growth or may decrease it slightly. Two lines of evidence indicate that the effects of pantoyl lactone do not result from a direct inactivation of penicillin. These are: (1) pantoyl lactone annuls the effects of a variety of chemically unrelated divisioninhibitory compounds; (2) pantoyl lactone can cause division of long bacterial forms which have been grown in the presence of penicillin for 12-16 hr.

The effects of all the penicillin derivatives tested in the present work were annulled by pantoyl lactone in a very similar manner (Tables 2, 3); at slightly toxic or near non-toxic concentrations of a penicillin, pantoyl lactone inhibited growth. 
Table 1. Effect of penicillin derivatives on growth and cell length of Erwinia

\begin{tabular}{|c|c|c|c|c|}
\hline Compound & Structure of side chain & $\begin{array}{c}\text { Concen- } \\
\text { tration } \\
\text { required } \\
\text { to produce } \\
\mathbf{5 0} \% \\
\text { inhibition } \\
\text { of growth } \\
(\mathrm{m} \mu \mathrm{mole} / \mathrm{ml} .)\end{array}$ & $\begin{array}{c}\text { Average } \\
\text { bacterial } \\
\text { length } \\
\text { estimated } \\
\text { at } 50 \% \\
\text { inhibition } \\
\text { of growth } \\
(\mu)\end{array}$ & $\begin{array}{c}\text { Bacterial } \\
\text { length } \\
\text { standard } \\
\text { deviation }\end{array}$ \\
\hline Benzylpenicillin & & 90 & 4.0 & 10 \\
\hline $\begin{array}{l}\text { DL- } \alpha \text {-Aminobenzylpeni- } \\
\text { cillin }(\mathrm{D}: \mathrm{L}=6: 4)\end{array}$ & $\mathrm{NH}_{2}$ & 10 & 45 & 9 \\
\hline D- $\alpha$-Aminobenzylpenicillin & $\mathrm{NH}_{2}$ & 12 & 36 & 8 \\
\hline $\begin{array}{l}\text { DL-3-Chloro- } \alpha \text {-amino- } \\
\text { benzylpenicillin }\end{array}$ & & 13 & 34 & 6 \\
\hline Methicillin & & 12 & 85 & 20 \\
\hline 6-Aminopenicillanic acid & $\mathrm{H}-$ & 80 & 45 & 10 \\
\hline Cloxacillin & & 88 & 70 & 9 \\
\hline $\begin{array}{l}\text { Triphenylmethyl- } \\
\text { penicillin }\end{array}$ & & 270 & 55 & 12 \\
\hline $\begin{array}{l}\text { 2-Ethoxy-1-naphthyl- } \\
\text { penicillin }\end{array}$ & & 310 & 86 & 10 \\
\hline
\end{tabular}


In some cases it was possible to distinguish different degrees of activity by pantoyl lactone with regard to division inhibition. For example, with D-ampicillin and 6-aminopenicillanic acid, bacteria grown with the penicillin alone in each case were about the same length. Added pantoyl lactone annulled growth-inhibition with each penicillin (when used at a toxic concentration) to a similar degree, yet the bacteria were much shorter with 6-aminopenicillanic acid. In general, the annulment by pantoyl lactone of division-inhibition by the aminobenzylpenicillins was poor.

Table 2. Prevention by pantoyl lactone of penicillin-induced accumulation of keto acids and ultraviolet-absorbing materials

\begin{tabular}{|c|c|c|c|c|c|c|}
\hline \multirow[b]{2}{*}{$\underset{(\mathrm{m} \mu \mathrm{mole} / \mathrm{ml} .)}{\text { Penicillin }}$} & \multicolumn{2}{|c|}{$\begin{array}{c}\text { Keto acids } \\
(\mu \mathrm{g} . / \mathrm{mg} . \text { dry wt. } \\
\text { bacteria) }\end{array}$} & \multicolumn{2}{|c|}{$\begin{array}{c}\text { Protein* } \\
\text { (mg./mg. dry wt. } \\
\text { bacteria) }\end{array}$} & \multicolumn{2}{|c|}{$\begin{array}{c}\text { Nucleic acid* } \\
\text { (mg./mg. dry wt. } \\
\text { bacteria) }\end{array}$} \\
\hline & Control & $\begin{array}{l}\text { Pantoyl } \\
\text { lactone } \\
(0 \cdot 042 \mathrm{M})\end{array}$ & Control & $\begin{array}{c}\text { Pantoyl } \\
\text { lactone } \\
(0 \cdot 042 \mathrm{M})\end{array}$ & Control & $\begin{array}{c}\text { Pantoyl } \\
\text { lactone } \\
(0 \cdot 042 \mathrm{M})\end{array}$ \\
\hline Benzylpenicillin 90 & 500 & 36 & $0 \cdot 44$ & $0 \cdot 085$ & $0 \cdot 31$ & 0.029 \\
\hline $\begin{array}{l}\text { oL- } \alpha \text {-Aminobenzyl- } \\
\text { penicillin } 35\end{array}$ & 290 & 45 & $0 \cdot 80$ & $0 \cdot 18$ & $0 \cdot 43$ & 0.05 \\
\hline $\begin{array}{l}\text { D- } \alpha \text {-Aminobenzyl- } \\
\text { penicillin } 76\end{array}$ & 230 & 90 & $1 \cdot 2$ & $0 \cdot 60$ & 0.51 & $\mathbf{0 \cdot 2 4}$ \\
\hline $\begin{array}{l}\text { 3-Chloro- } \alpha \text {-amino- } \\
\text { benzylpenicillin } 33\end{array}$ & 200 & 29 & $0 \cdot 44$ & $0 \cdot 12$ & $0 \cdot 13$ & 0.05 \\
\hline Methicillin 76 & 1800 & 50 & $1 \cdot 3$ & 0.52 & $1 \cdot 4$ & $\mathbf{0 \cdot 1 0}$ \\
\hline Cloxacillin 35 & 910 & 38 & 0.43 & $0 \cdot 11$ & $0 \cdot 22$ & 0.034 \\
\hline $\begin{array}{l}\text { 6-Aminopenicil- } \\
\text { lanic acid } 65\end{array}$ & 230 & 50 & $0 \cdot 34$ & $0 \cdot 09$ & $0 \cdot 23$ & 0.036 \\
\hline $\begin{array}{l}\text { Triphenylmethyl- } \\
\text { penicillin } 60\end{array}$ & 1240 & 12 & $0 \cdot 44$ & $0 \cdot 08$ & 0.08 & $0 \cdot 05$ \\
\hline $\begin{array}{l}\text { 2-Ethoxy-1-naph- } \\
\text { thyl-penicillin } 326\end{array}$ & 280 & 56 & $\mathbf{0 \cdot 2 4}$ & $0 \cdot 07$ & $0 \cdot 11$ & 0.033 \\
\hline
\end{tabular}

* Determined from $260 / 280 \mathrm{~m} \mu$ extinetion ratio of culture supernatant fluids.

Table 3. Pantoyl lactone annulment of growth-inhibition and divisioninhibition of an Erwinia caused by penicillin derivatives

\begin{tabular}{|c|c|c|c|c|c|}
\hline & \multicolumn{2}{|c|}{ Growth* } & \multicolumn{2}{|c|}{$\begin{array}{l}\text { Average bacterial } \\
\text { length }(\mu)\end{array}$} & \multirow{2}{*}{$\begin{array}{c}\text { Ratio of } \\
\text { average } \\
\text { length } \\
\text { control/ } \\
\text { pantoyl } \\
\text { lactone } \\
(0.042 \mathrm{M})\end{array}$} \\
\hline Penicillin ( $\mathrm{m} \mu \mathrm{mole} / \mathrm{ml}$.) & Control & $\begin{array}{l}\text { Pantoyl } \\
\text { lactone } \\
(0 \cdot 042 \mathrm{M})\end{array}$ & Control & $\begin{array}{l}\text { Pantoyl } \\
\text { lactone } \\
(0.042 \mathrm{M})\end{array}$ & \\
\hline ylpenicillin 90 & $0 \cdot 25$ & $0 \cdot 68$ & 55 & 7 & $7 \cdot 8$ \\
\hline Aminobenzylpenicillin 35 & $0 \cdot 20$ & $0 \cdot 64$ & 49 & 11 & $4 \cdot 4$ \\
\hline Aminobenzylpenicillin 76 & $0 \cdot 15$ & $0 \cdot 21$ & 30 & 22 & $1 \cdot 4$ \\
\hline ro- $\alpha$-Aminobenzylpenicillin $\mathbf{3 3}$ & $0 \cdot 24$ & 0.77 & 37 & 7 & $\mathbf{5} \cdot \mathbf{3}$ \\
\hline inopenicillanic acid 65 & $0 \cdot 80$ & $0 \cdot 68$ & 37 & $3 \cdot 5$ & $10 \cdot 6$ \\
\hline cillin 35 & 0.96 & $0 \cdot 80$ & 38 & $3 \cdot 5$ & $10 \cdot 8$ \\
\hline icillin 76 & 0.07 & $0 \cdot 60$ & 100 & $\mathbf{2 4}$ & $4 \cdot 1$ \\
\hline enylmethylpenicillin 60 & $1 \cdot 10$ & 0.95 & 13 & $2 \cdot 7$ & $4 \cdot 9$ \\
\hline & $0 \cdot 09$ & 0.54 & 110 & 36 & $3 \cdot 1$ \\
\hline 10xy-1-naphthylpenicillin 326 & $0 \cdot 48$ & 0.69 & 110 & 13 & 8.5 \\
\hline
\end{tabular}

* Extinction $\left(E_{540}\right)$ at $16 \mathrm{hr}$. 


\section{DISCUSSION}

The similarity in the biological effects of the penicillins tested on this Erwinia supports the theory that the basis of penicillin action lies in the nucleus of the molecule, in agreement with the conclusions of Cooper (1956) and others. Since the side chain is not essential for the basic activity of penicillin, its influence on activity as observed by Boman \& Eriksson (1963) may be a reflexion of its influence on the rate of binding at the active site and on the strength of the bond formed. After binding, the activities of different penicillins are similar. Rolinson (1962) reached the same conclusion after comparing the bactericidal activity of different penicillins in non-limiting concentrations. Apparent differences in activity he believed to result from differences in affinity of the molecule for the active site. To our knowledge little has been done on the influence of the side chain on the rate of uptake, or on the firmness of attachment at the active site. Mohberg \& Johnson (1958) found that cephalosporin $\mathbf{N}$ was bound much less rapidly than benzylpenicillin. While we recognize that differences in permeability of an organism to different penicillins may be a factor in determining their relative activities, other factors must transcend permeability as the source of these differences. If permeability alone were the basis of our results, the effects on growth and bacterial length should parallel each other, which they do not (Table 1).

It is reasonable that the influence of the side chain should depend in part on the chemical nature of the receptors at the active site (see Cooper, 1956) and on permeability characteristics of the cell membrane and that different bacteria will show differences in the relative activities of different penicillin derivatives. This is illustrated by a comparison of our results with those of Boman \& Eriksson (1963). With two compounds, 6-aminopenicillanic acid and methicillin, we observed a far higher activity with the Erwinia than Boman \& Eriksson did with Escherichia coli. The potency of methicillin with the Erwinia indicates that a bulky side chain on the molecule does not necessarily preclude a high degree of activity; cloxacillin (not used by Boman \& Eriksson), another penicillin with a large side chain, showed high activity for the Erwinia. On the other hand, two penicillins with bulky side chains, triphenylmethylpenicillin and 2-ethoxy-1-naphthylpenicillin, were only about onetwentieth as toxic as methicillin.

The possibility that side-chain structure may affect the intrinsic activity of the molecule must be recognized. The greater toxicity of the aminobenzylpenicillins than benzylpenicillin, originally observed with some Gram-negative bacteria (Rolinson \& Stevens, 1961), may be an example; this higher activity also applies to specific enzyme systems (Rogers \& Mandelstam, 1962). In our case, the relatively poor annulment by pantoyl lactone of the inhibitions by the aminobenzylpenicillins could be interpreted as indicating increased intrinsic activity toward the Erwinia resulting from the presence of a primary $\alpha$-amino group in the side chain.

Collins \& Richmond (1962) proposed that the structural similarity between $\mathrm{N}$-acetylmuramic acid and penicillin might serve as a basis for antibiotic action. With molecular models, they showed that three atoms in the penicillin molecule, viz. $\mathbf{O}$ of the amide linkage of the side chain, $\mathbf{N}$ of the $\beta$-lactam ring, and $\mathbf{O}$ of the carboxyl group, all capable of forming hydrogen bonds, correspond in relative position to three atoms of $\mathrm{N}$-acetylmuramic acid, also capable of forming hydrogen 
bonds. The action of penicillin might then be explained on the basis that the antibiotic occupies the site normally occupied by $\mathrm{N}$-acetylmuramic acid on an enzyme. Alteration of the relative positions of these atoms in penicillin is sufficient to destroy activity; an example is the $\beta$-lactam ring opening caused by penicillin $\beta$-lactamase (Pollock, 1962). However, removal of oxygen from the amide link of the side chain does not destroy activity, or even necessarily decrease it 1000-fold, as stated by Collins \& Richmond (1962). In the case of the Erwinia, 6-aminopenicillanic acid (no side chain) was as toxic and as effective to inhibit division as benzylpenicillin. Our results with the Erwinia do not support the hypothesis of Collins \& Richmond (1962), nor do the results of Hugo \& Russell (1960), who observed that the concentration of 6-aminopenicillanic acid needed to induce spheroplasts in Gram-negative bacteria was only about twice as great as that for benzylpenicillin.

That inhibition of mucopeptide synthesis is the sole action of penicillin is a hypothesis not adequate to explain all the effects of penicillin; the partial independence of growth-inhibition and division-inhibition shown by the penicillins we have tested is a case in point. Grula \& Grula (1964) showed that restoration of the ability to divide to penicillin-inhibited bacteria by adding pantoyl lactone was not accompanied by a restoration of cell-wall mucopeptide synthesis; division-inhibition is not a consequence only of inhibition of mucopeptide synthesis. The decrease in release of ultraviolet-absorbing materials, and in the accumulation of keto acids caused by adding pantoyl lactone may be because of protection afforded the cell membrane by this compound. The relationship of these effects of pantoyl lactone to its ability to prevent division inhibition is not known; however, evidence has been presented (Grula \& Grula, 1964) that membrane damage occurs under most conditions of division-inhibition.

The ability of penicillin or its derivatives to inhibit bacterial division, as well as other biological activities, is a property of the $\beta$-lactam ring of the nucleus of the molecule. The effect of the side chain is not on the intrinsic activity, but on the affinity of the molecule for the active site. Factors independent of the penicillin which may affect binding, some of which may vary with the species (chemical nature of receptor sites, permeability) would be expected to influence the observed relative activities of various penicillins.

We wish to thank Dr F. P. Doyle, Director of Research, Beecham Research Laboratories Ltd., for generously supplying us with the penicillin derivatives. This study was supported in part by a research grant GB-1532 from the National Science Foundation, U.S.A., and a U.S. Public Health Service research career program award (GM-13,968) from the Division of General Medical Sciences.

\section{REFERENCES}

Abraham, E. P., Crawford, K., Newton, G. F., Burton, H. S. \& Hale, E. W. (1953). Cephalosporin $\mathrm{N}$ : a new type of penicillin. Nature, Lond. 171, 343.

Boman, H. G. \& Eriksson, K. G. (1963). Penicillin-induced lysis in Escherichia coli. J. gen. Microbiol. 31, 339.

Collins, J. F. \& Richmond, M. H. (1962). A structural similarity between $N$-acetylmuramic acid and penicillin as a basis for antibiotic action. Nature, Lond. 195, 142.

Cooper, P. D. (1956). Site of action of radioactive penicillin. Bact. Rev. $20,28$. 
Grula, E. A. $(1960 a)$. Cell division in a species of Erwinia. I. Initial observations relating to nutritional dependency. J. Bact. 80, 369.

GrUlA, E. A. (1960b). Cell division in a species of Erwinia. II. Inhibition of division by D-amino acids. J. Bact. 80, 375.

Grula, E. A. \& Grula, M. M. (1962). Cell division in a species of Erwinia. III. Reversal of inhibition of cell division caused by $\mathrm{D}$-amino acids, penicillin, and ultraviolet light. J. Bact. 83, 981.

Grula, E. A. \& Grula, M. M. (1964). Cell division in a species of Erwinia. VII. Amino sugar content of dividing and non-dividing cells. Biochem. Biophys. Res. Comm. 17, 341.

HaIdLe, C. W. \& KNIGHT, S. G. (1960). A colorimetric assay for 2-heptanone and other ketones. Biochim. biophys. Acta, 39, 536.

Hugo, W. B. \& Russels, A. D. (1960). Action of 6-aminopenicillanic acid on Gram negative bacteria. Nature, Lond. 188, 875.

Mohberg, J. \& Jomnson, M. J. (1958). Comparative study of the binding of synnematin and penicillin by bacterial cells. J. Bact. 76, 385.

Pollock, M. R. (1962). Penicillinase. In Resistance of Bacteria to the Penicillins. CIBA Foundation Study Group, no. 13, p. 56. London: J. and A. Churchill Ltd.

Rogers, H. J. \& Mandelstam, J. (1962). Inhibition of cell-wall-mucopeptide formation in Escherichia coli by benzylpenicillin and 6-(D( - )- $\alpha$-aminophenylacetamido) penicillanic acid ('ampicillin'). Biochem. J. 84, 299.

Rolinson, G. N. (1962). cf. Discussion on mode of action of the penicillins, by H.J. Rogers. In Resistance of Bacteria to the Penicillins, CIBA Foundation Study Group, no. 13, p. 47. London: J. and A. Churchill Ltd.

Rournson, G. N. \& Stevens, S. (1961). Microbiological studies on a new broad-spectrum penicillin, 'Penbritin'. Br. med. J. ii, 191.

Russels, A. D. (1962). A note on the activity of six penicillins against Escherichia coli. J. Pharm., Lond. 14, 390. 